\title{
SIKAP BELAJAR KAITANNYA DENGAN HASIL BELAJAR IPA SISWA MADRASAH TSANAWIYAH AL MAARIF PRAYA TIMUR KABUPATEN LOMBOK TENGAH
} THE RELATIONSHIP OF LEARNING ATTITUDE AND SCIENCE LEARNING ACHIEVEMENT OF
STUDENTS IN MADRASAH TSANAWIYAH AL MAARIF PRAYA TIMUR CENTER OF LOMBOK

\author{
Mohmmad Liwa Ilhamdi*, Agil Al Idrus, dan Didik Santoso \\ Program Studi Pendidikan Biologi FKIP Universitas Mataram, Mataram, Indonesia \\ *Email: liwa_ilhamdi@unram.ac.id
}

Diterima: 29 Desember 2020. Disetujui: 3 Januari 2021. Dipublikasikan: 20 Januari2021

\begin{abstract}
Abstrak: Hasil belajar merupakan salah satu indikator keberhasilan dalam proses pembelajaran. Mata pelajaran IPA dipelajari sejak tingkat Sekolah Menengah Pertama (SMP). Mata pelajarn IPA merupakan salah satu mata pelajaran yang diujian nasionalkan. Oleh karena itu siswa diharapkan memiliki hasil belajar IPA yang baik agar dapat lulus dalam ujian nasional. Sikap belajar menjadi bagian dari faktor yang mempengaruhi hasil belajar IPA. Penelitian ini bertujuan untuk mengetahui sikap belajar IPA siswa kaitannya dengan hasil belajar IPA. Jenis penelitian adalah deskriptif kuantitatif. Penelitian ini dilakukan di MTs Al Ma'arif Praya Timur. Populasi dalam penelitian ini adalah seluruh siswa di MTs Al Ma'arif Praya Timur. Metode pengupmpulan data dengan angket dan dokumentasi. Hasil penelitian menunjukkan rata rata skor angket sikap 71.70. sedangkan rata rata hasil belajar IPA 72.75 Hasil analisis data $r$ hit 0.45 dan $r$ table 0.44 (rhit>rtabel). Kesimpulan ada kaitan yang signifikan antara sikap belajar dengan hasil belajar IPA siswa M.Ts. Al Ma'arif Praya Timur. Signifikansi positif ini menunjukkan bahwa semakin tinggi sikap belajar terhadap IPA semakin tinggi pula hasil belajar IPA yang diraihnya.
\end{abstract}

Kata Kunci: Sikap Belajar, Hasil belajar IPA

\begin{abstract}
Learning outcomes are an indicator of success in the learning process. Science subjects are studied at the Junior High School level. Science subject is one of the subjects that is nationalized. Therefore, students are expected to have good science learning outcomes in order to pass the national exam. Learning attitudes are part of the factors that affect science learning outcomes. This study aims to determine students' science learning attitudes in relation to science learning outcomes. This type of research is descriptive quantitative. This research was conducted at MTs Al Ma'arif Praya Timur. The population in this study were all students at MTs Al Ma'arif Praya Timur. Data collection methods using questionnaires and documentation. The results showed the average score for attitude questionnaire was 71.70. while the average science learning outcomes 72.75 Results of data analysis $r$ count 0.45 and $\mathrm{r}$ table 0.44 ( $\mathrm{r}$ count> $\mathrm{r}$ table). The conclusion is that there is a significant relationship between learning attitudes and science learning outcomes of MTs students. Al Ma'arif Praya Timur. This positive significance indicates that the higher the learning attitude towards science, the higher the science learning outcomes one achieves.
\end{abstract}

Keywords: Learning attitude, student achievement of science learning

\section{PENDAHULUAN}

Pendidikan merupakan salah satu indikator kemakmuran suatu bangsa. Melalui pendidikan harkat dan martabat suatu negara dapat diangkat. Pendidikan wajib di negara Indonesia terdiri dari tiga tingkatan, yakni Sekolah Dasar, Sekolah Menengah Pertama dan Sekolah Menengah Atas. Diharapkan dengan mewajibkan sekolah selama 12 tahun kualitas sumber daya manusia dapat meningkat. Peningkatan sumber daya manusia yang dimiliki oleh negara akan memberikan kontribusi yang besar dalam menyambut bonus demografi 2045 [1].

Hampir seluruh siswa yang datang ke sekolah memiliki keinginan yang sama yakni untuk meningkatkan kapasitas dirinya. Peningkatan kapasistas diri bertujuan untuk mendapatkan kesuksesan di masa yang akan datang [2]. Kesuksesan dalam studi menjadi salah satu faktor pendukung kesuksesan siswa di masa mendatang. Kesuksesan dalam studi dipengaruhi oleh berbagai faktor, baik faktor yang berasal dari dalam maupun luar diri siswa. Faktor yang berasal dari luar diri siswa meliputi kegiatan belajar, model pembelajaran, keadaan lingkungan, latar belakang sosial dan budaya serta latar belakang ekonomi yang kerap kali mempengaruhi hasil belajar siswa [3]. Faktor dari dalam diri siswa yang dapat mempengaruhi hasil belajar yakni motivasi, psikologi, bakat, mental dan sikap siswa [4].

Sikap merupakan kecenderungan mental yang melekat dalam diri seseorang dalam menghasilkan ide maupun kebiasaan ketika memberikan respon terhadap situasi tertentu [6] [5]. Lebih lanjut Shah dkk. 2019 mendefinisikan sikap sebagai proses kompleks dalam pikiran yang direfleksikan dalam kebiasaan. Sikap dapat diukur 
dengan dua cara yakni hanya mengukur afektifnya saja sedangkan kognitif dan psikomotornya diukur terpisah atau dengan cara mengukur ketiga aspek secara bersamaan.

Sikap terhadap kegiatan pembelajaran dapat menjadi alat pengendalian diri bagi siswa. Dengan memiliki sikap positif maka siswa dapat memposisikan dirinya selama proses pembelajaran. Kewajiban seorang guru adalah memastikan bahwa setelah selesai sekolah siswa tetap mampu mengatur diri mereka untuk tetap belajar [2]. Umumnya kesuksesan dari proses pembelajaran dipengaruhi oleh kualitas dan cara mengajar guru [8]. Akan tetapi selama ini sikap negatif siswa terhadap kegiatan pembelajaran menjadi penyebab kegagalan guru dalam menghantarkan anak didiknya pada perkembangan yang optimal. Ahmadi 1991 mengatakan bahwa siswa-siswa baik sekolah dasar, sekolah menengah bahkan mahasiswa kerap kali memberikan bukti kegagalan belajar disebabkan oleh ketidakefektifan siswa dalam belajar. Selanjutnya dijelaskan bahwa keberhasilan dalam belajar akan datang jika kita mempunyai cara-cara belajar yang efektif dan efesien, sikap belajar yang positif maupun kebiasaan yang baik dalam belajar.

Kesuksesan dalam studi salah satunya dapat dilihat dari hasil belajar yang dicapai oleh siswa. Hasil belajar merupakan perubahan yang dialami oleh siswa melalui serangkaian pengalaman belajar. Hassan 2016 mendefinisikan hasil belajar sebagai suatu sudut pandang terkait cara individu menyelesaikan tugas kognitifnya. Hasil belajar siswa akan mencerminkan ketercapaian tujuan pembelajaran [11]. Adapun hasil belajar terbagi menjadi tiga ranah, yakni ranah kognitif, ranah afektif dan ranah psikomotorik. Hasil belajar yang akan difokuskan dalam artikel ini adalah hasil belajar ranah kognitif. Anderson dan Krathwol 2015 menyatakan bahwa kognitif berkaitan dengan perubahan prilaku akibat berbagai proses mental yang dialami oleh seseorang. Lebih lanjut dijelaskan bahwa aspek konitif dibagi menjadi enam tingkatan yakni (1) pengetahuan (knowledge) yang berhubungan dengan kemampuan menghafal dan mengingat, (2) memahami (comprehension) yakni kammpuan memahami suatu konsep, (3) menerapkan (aplication) yaitu kemampuan dalam mengaplikasikan pengetahuan yang telah diperoleh dalam konsep lain, (4) menganalis (analysis) berkaitan dengan kemampuan memilah, menguraikan informasi dalam bagian-bagiannya serta hubungannya, (5) mengevaluasi (evaluate) yakni kemampuan siswa dalam merangkai suatu polaataupun struktur dari hal yang telah ada sebelumnya, (6) mencipta (create) yaitu kemampuan untuk membuat suatu hal yang baru.

Ilmu Pengetahuan Alam atau yang lebih sering disingkat dengan IPA mulai dikenalkan sejak pendidikan Sekolah Dasar. IPA merupakan cabang dari ilmu pengetahuan yang mempelajari gejaa-gejala alam. Ilmu Pengetahuan Alam didapatkan memlalui fakta, konsep, hipotesis maupun teori. Pendidikan IPA memilki peran yang penting dalam perkembangan ekonomi dan teknologi suatu negara. Mewadahi siswa untuk belajar IPA merupakan suatu langkah persiapan kemajuan bagi suatu negara [7]. Dengan belajar IPA maka siswa dibiasakan untuk menggunakan keterampilannya dalam menemukan solusi dari permasalahan yang kompleks. Kepercayaan diri siswa dalam mengambil keputusan ini sangat dibutuhkan ditengah arus perkembangan teknologi yang hampir tidak terkendali ini. Oleh karena itu pelajaran IPA sangatlah penting untuk dipelajari [13].

Hasil belajar akan lebih bermanfaat apabila tidak mudah dilupakan oleh siswa. Hasil belajar yang tidak maksimal berpotensi mengakibatkan rendahnya Sumber Daya Manusia dan menyebabkannya tidak mampu bersaing [14]. Dengan meningkatnya hasil belajar IPA, diharapkan dapat menjadi pengetahuan awal bagi siswa untuk bersaing dimasa mendatang.

Sikap siswa terhadap belajar ini penting untuk diteliti karena sikap belajar siswa mempunyai pengaruh yang tidak sedikit terhadap keberhasilan, peningkatan hasil belajar siswa, sebab prilaku atau tindakan belajar sangat ditentukan oleh sikap belajar. Diungkap oleh Saifuddin 1988 bahwa sikap adalah kecenderungan untuk bertindak terhadap target. Siswa yang mempunyai sikap positif terhadap sesuatu cenderung bertingkah laku positif terhadap objek tersebut. Tanpa sikap yang positif, ulet, tekun, siswa mudah putus asa dan tidak bertahan terhadap berbagai kesulitan-kesulitan yang muncul. Akan tetapi ketertarikan kaum muda terhadap pembelajaran khususnya bidang sains, saat ini mulai menurun. Jumlah kaum muda yang mengambil mata pelajaran sains juga semakin menurun, hal ini dikarenakan jenjang karir dibidang sains dirasa kurang menarik [16].

Hasil studi pendahuluan menunjukkan bahwa masih ada siswa yang belum menyadari bahwa dengan bersikap positif terhadap belajar akan memperoleh hasil yang baik. Sebagian beranggapan bahwa tanpa cara dan metode yang terencana, tanpa selalu ulet, asal-asalan pun dapat memperoleh nilai yang diharapkan, paling tidak nilai lulus dapat diraihnya. Oemar 2001 mengemukakan bahwa ada beberapa kesalahan umum yang sering dilakukan siswa tentang belajar diantaranya belajar asal belajar saja tanpa tujuan yang hendak dicapai, belajar tanpa rencana, bersikap pasif dalam mengikuti pelajaran serta bersikap tidak suka belajar bersama.

Hasil penelitian Dadang 1984 pada siswa di Jawa Barat menunjukkan bahwa banyak siswa mempunyai hasil belajar rendah karena mempunyai sikap belajar yang pada umumnya rendah. Lebih lanjut dia menjelaskan sikap belajar yang rendah akan menyebabkan hasil belajar yang rendah pula 
karena untuk belajar yang efektif dan efesien diperlukan rasa senang (sikap yang positif) terhadap belajar, sehingga dapat mencapai hasil yang diharapkan. Menurut Dimyati 1999 tidak mungkin seorang siswa memperoleh nilai yang bagus tanpa memperhatikan belajarnya, bersikap yang baik. Hasil observasi awal pada beberapa jenjang pendidikan terkait sikap belajar pada penelitian terdahulu, menunjukkan siswa pada jenjang Sekolah Dasar hingga perguruan tinggi memiliki sikap belajar yang negatif [20] [21] [22].

MTs. Al Ma'arif Praya Timur dipilih sebagai objek penelitian karena sekolah umum dan status negeri sudah sering dijadikan objek penelitian oleh peneliti sebelumnya. Sedangkan sekolah ini adalah sekolah agama dan swasta yang harus melaksanakan pembelajaran yang lebih banyak dibandingkan sekolah umum lainnya, yaitu mata pelajaran agama dan umum. Dari uraian di atas maka perlu diadakan penelitian yang berhubungan dengan sikap belajar khususnya sikap belajar siswa sekolah agama terhadap pelajaran umum (IPA) karena mata pelajaran IPA merupakan salah satu mata pelajaran yang diajarkan di sekolah agama dan diujian nasionalkan serta kaitanya dengan hasil belajar IPA yang diraihnya.

\section{METODE PENELITIAN}

Jenis penelitian deskriptif dengan menjelaskan fenomena-fenomena yang ada. Populasi dalam penelitian ini adalah seluruh siswa MTs. Al Ma'arif Praya Timur Lombok Tengah. Teknik sampling dalam penelitian ini adalah sampel populasi karena seluruh populasi dijadikan sampel.

Pengumpulan data dilakukan dengan mengacu pada jenis data yang dibutuhkan. Dalam penelitian ini dibutuhkan dua jenis data, yakni data kuantitatif dan kualitatif. Oleh karena itu alat pengumpul data yang digunakan dalam penelitian ini berupa angket dan dokumentasi raport siswa.

Data sikap belajar diperoleh dengan menggunakan angket. Angket sikap belajar dikembangkan dengan menggunakan skala Likert yang terdiri dari empat pilihan jawaban yakni "sangat setuju", "setuju", "kurang setuju" dan "tidak setuju". Angket sikap belajar terdiri dari 40 butir soal pernyataan. Pernyataan dalam angket ini kemudian diuji validitas dan reliabilitasnya. Berdasarkan hasil uji validitas dan reliabilitas didapatkan 32 butir pernyataan yang terdiri dari 18 pernyataan negatif dan 14 pernyataan positif. Angket sikap belajar kemudian diberikan kepada seluruh sampel penelitian secara langsung. Siswa diwajibkan mengisi angket sikap belajar ketika berada di sekolah, dan tidak boleh dibawa pulang untuk disi di rumah. Jenis data yang kedua yakni data hasil belajar. Data hasil belajar diperoleh dengan cara mendokumentasikan nilai raport siswa pada mata pelajaran IPA.
Data nilai raport yang telah terkumpul kemudian dianalisis secara kualitatif dan kuantitatif. Analisis kualitatif dilakukan dengan melihat skor perolehan dari angket sikap belajar terhadap IPA kemudian dikonversikan dengan tingkatan skala sikap yaitu sangat suka, suka, kurang suka dan tidak suka terhadap IPA. Analisis data kuantitatif dilakukan dengan uji $r$ product moment untuk mengetahui kaitan antara sikap belajar IPA dengan hasil belajarnya [23]. Adapun rumus $r$ product moment dapat dilihat pada Gambar 1.

$$
\begin{aligned}
& \mathrm{r}_{\mathrm{xy}}=\frac{n \sum X Y-\left(\sum X\right)\left(\sum Y\right)}{\sqrt{\left[n \sum X^{2}-\left(\sum X\right)^{2}\right\}\left(n \sum Y^{2}-\left(\sum Y\right)^{2} Y\right.}} \\
& \text { Gambar 1. Rumus } r \text { product moment }
\end{aligned}
$$

\section{HASIL DAN PEMBAHASAN}

Hasil pengumpulan data menunjukkan bahwa data skor angket sikap belajar IPA siswa MTs. Al Ma'arif Praya Timur yang didapatkan sangat beragam. Hal yang sama juga ditemukan pada data hasil belajar yang diperoleh dengan cara dokumentasi raport siswa (Tabel 1).

Tabel 1. Skor Sikap dan Hasil Belajar Siswa MTs Al Ma'arif

\begin{tabular}{lllll}
\hline & $\begin{array}{l}\text { Jumlah } \\
\text { Nilai }\end{array}$ & Tertinggi & Terendah & $\begin{array}{l}\text { Rata- } \\
\text { Rata }\end{array}$ \\
\hline $\begin{array}{l}\text { Sikap } \\
\text { IPA }\end{array}$ & 1434 & 78 & 60 & 71.70 \\
$\begin{array}{l}\text { Hasil } \\
\text { Belajar }\end{array}$ & 1455 & 80 & 65 & 72.75 \\
\hline
\end{tabular}

Berdasarkan hasil analisis data dengan menggunakan korelasi $r$ - product moment diperoleh nilai r- hitung $0, .45$ sedangkan $\mathrm{r}$ - tabel 0.44 (r-hitung $>$ r-tabel). Hal ini menunjukkan terdapat korelasi yang positif antara sikap belajar dengan hasil belajar IPA yang diraih siswa. Semakin tinggi atau semakin positif sikap belajar siswa terhadap IPA, maka semakin tinggi pula nilai IPA yang diperolehnya.

Hasil analisis data menunjukkan adanya hubungan yang positif antara sikap belajar dan hasil belajar siswa. Sikap belajar siswa yang positif akan membantu siswa untuk menentukan cara belajar yang efektif dalam memahami materi pembelajaran [24] [25]. Berbagai penelitian telah dilakukan terkait sikap belajar dan hasil belajar [26] [27]. Dibutuhkan sikap yang positif untuk mencapai suatu rencana belajar artinya apabila kita memililki sikap yang positif maka hasil yang diperoeh akan lebih baik [28]. Seorang siswa yang melaksanakan proses belajar, harus mempunyai sikap yang optimis bahwa semua kondisi dan fasilitas yang baik jika dimanfaatkan secara optimal akan mendukung tercapainya hasil belajar yang maksimal [29]. Demikian juga seorang siswa harus meyakini dan 
merasa bahwa dalam proses pembelajaran dibutuhkan sikap positif untuk menemukan tujuan belajar, cara-cara yang efektif, rasa suka dan senang terhadap pelajaran sehingga hasil belajar pada mata pelajaran itu menjadi tinggi [30].

Data hasil penelitian terkait sikap belajar dan hasil belajar juga dianalaisis menggunakan analaisis regresi yang menunjukkan bahwa daya ramal grafik kuadratik lebih tinggi dibandingkan dengan grafik linear $\left(\mathrm{R}^{2}\right.$ kuadratik $=0.297>\mathrm{R}^{2}$ linear $=0.171)$. Persamaan garis dari grafik kuadratik adalah $y=-10.71 x^{2}+0.08 x+426.477$. Persamaan garis dari grafik liear adalah $y=0.486 x+37.87$. Dimana $y$ adalah hasil belajar dan $x$ adalah sikap belajar. Adapaun grafik yang menunjukkan hubungan antara sikap belajar dan hasil belajar dapat diamati pada Gambar 2 dan Gambar 3.

Grafik kuadratik memberikan gambaran bahwa hasil belajar siswa dipengaruhi oleh sikap siswa terhadap pembelajaran. Siswa yang memiliki sikap positif terhadap pembelajaran akan memiliki hasil belajar yang baik. Hal ini dapat diamati dari nilai siswa yang terobservasi lebih banyak mendekati garis kurva pada grafik. Berdasarkan hasil analisis regresi juga ditemukan persamaan kuadratik, dimana apabila nilai $X$ dimasukkan ke dalam persamaan maka hasil belajar dari siswa dapat diketahui. Penelitian terkait sikap belajar dan hasil belajar sudah banyak diteliti, namun beberapa penelitian menunjukkan hubungan yang negatif seperti hasil penelitian Rennie dan Punch, 1991. Hasil penelitian yang dilakukan oleh Rennie dan Punch menunjukkan bahwa sikap belajar dan hasil belajar memiliki hubungan yang tidak signifikan pada siswa kelas delapan. Namun Hasil penelitian terkini menunjukan hubungan yang signifikan anatara sikap belajar siswa dengan hasil belajar IPA [20,24-25,30,32-35].

\section{Hasil_Belajar}

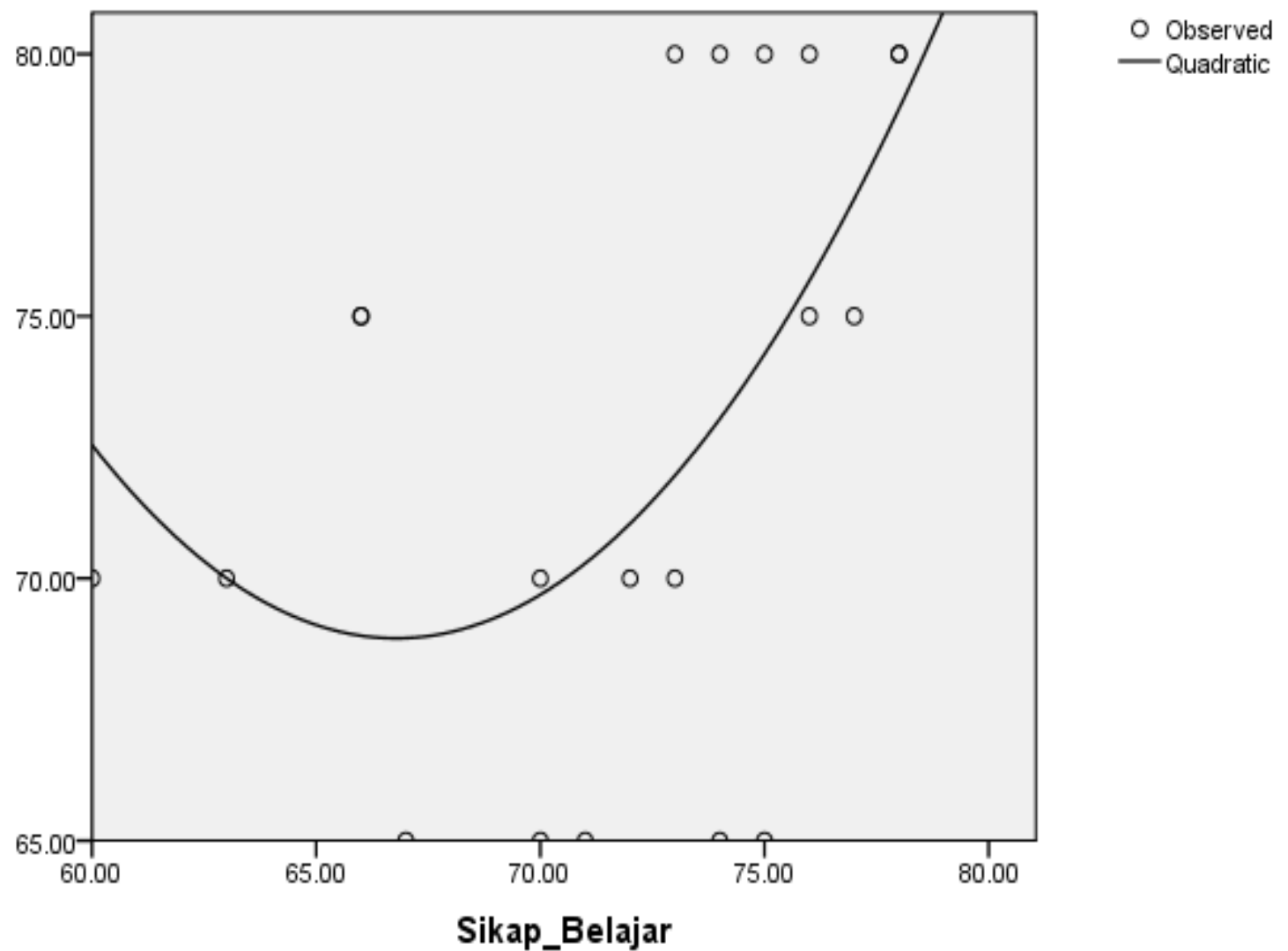

Gambar 2. Grafik kuadratik hubungan antara sikap belajar siswa dengan hasil belajar IPA pada MTs. Alma'arif Praya Timur

Grafik linearitas menunjukkan hasil yang sama dengan grafik kuadratik. Akan tetapi daya ramal dari grafik linearitas hasil analsis data ini lebih rendah daya ramalnya dibandingkan grafik kuadratik. Apabila nilai sikap siswa terhadap pelajaran IPA disubstitusikan ke dalam persamaan kuadratik maka akan didapatkan nilai hasil belajar dari siswa. Namun persmaan linear ini kurang akurat dalam memprediksi nilai hasil belajar siswa.

Hasil belajar dipengaruhi oleh faktor internal dan faktor eksternal. Salah satu faktor internal yang dapat mempengaruhi hasil belajar adalah faktor dari sikap belajar [36]. Sikap belajar yang positif memberikan hasil belajar yang baik [35]. 
Sebab untuk bisa belajar dengan efektif diperlukan rasa senang (sikap yang positif) terhadap belajar. Sikap belajar yang positif akan membantu siswa dalam mengetahui cara belajar yang baik, membangun harapan yang baru dan mengurangi kecemasan ketika pembelajaran sedang berlangsung [5] Dengan demikian dapat dikatakan bahwa seorang siswa yang bersikap belajar positif terhadap IPA cenderung akan mempunyai hasil belajar IPA yang lebih baik.

\section{Hasil_Belajar}

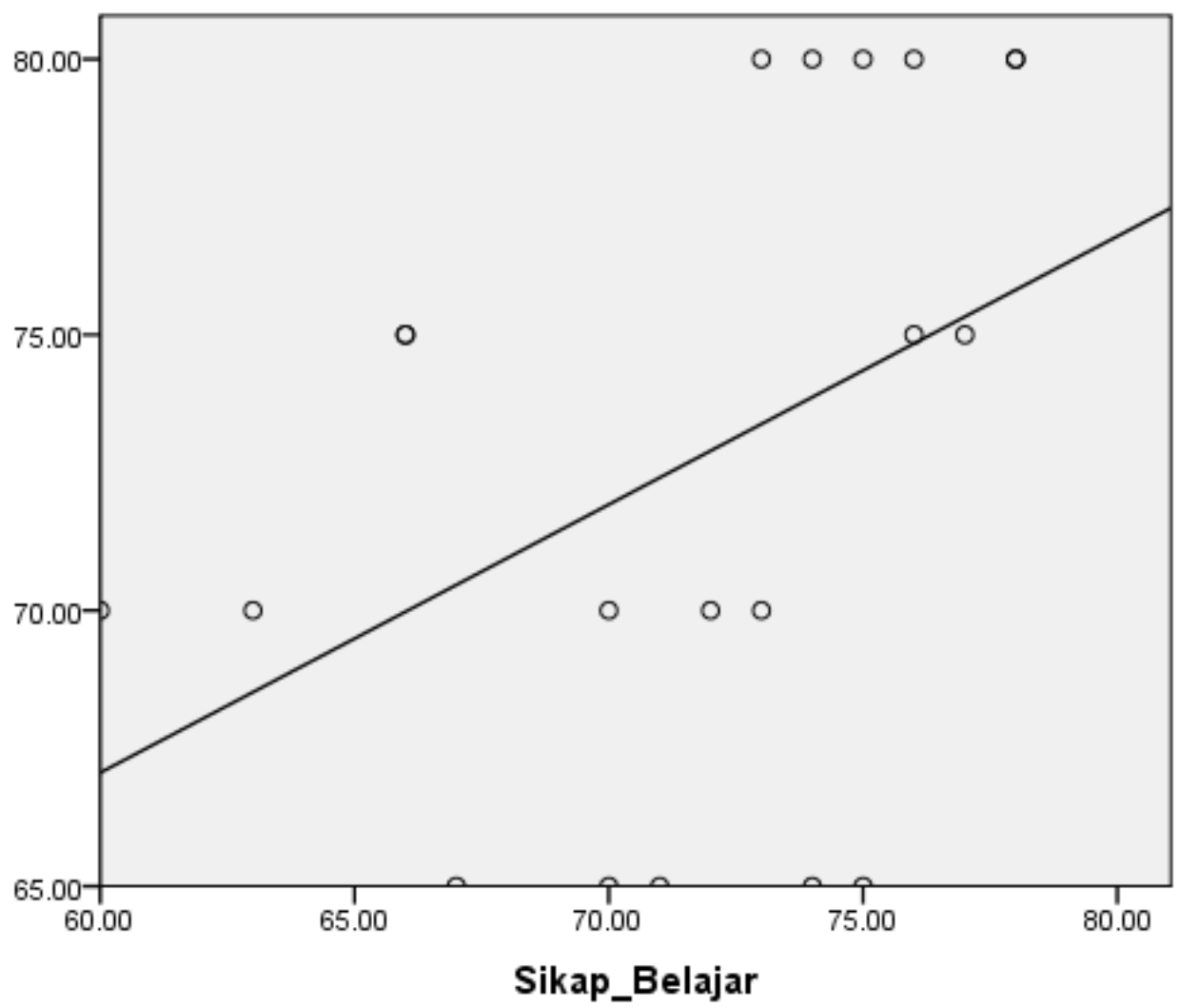

Gambar 3. Grafik linear hubungan antara sikap belajar siswa dengan hasil belajar IPA pada MTs. Alma'arif Praya Timur

Analisis kualitatif data angket sikap siswa terhadap pelajaran IPA menunjukkan bahwa siswa MTs. Al Ma'arif Praya Timur 75\% siswanya mempunyai sikap yang suka terhadap IPA dan $25 \%$ siswa berada pada kriteria sangat suka terhadap IPA (Tabel 2).

Siswa MTs. Al Ma'arif Praya Timur memiliki sikap yang positif terhadap pelajaran IPA. Hal ini dapat dilihat pada hasil analisis data yang menunjukkan tidak ada siswa yang memiliki sikap negatif terhadap pelajaran IPA. Siswa mulai merasa senang terhadap pelajaran IPA, dan mulai menyadari penting mempelajari IPA sebagai modal menghadapi perubahan zaman. Hasil penelitian ini didukung oleh hasil penelitian terdahulu bahwa siswa sudah mulai menyadari pentingnya mempelajari IPA [37][16][13]. Sikap positif terhadap pelajaran IPA ini diharapkan tetap dipertahankan oleh siswa hingga mereka menyelesaikan studinya.
Data hasil dokumentasi nilai IPA raport siswa MTs. Al Ma'arif Praya Timur menunjukkan bahwa kriteria hasil belajar siswa tergolong ke dalam kelompok sedang dan tinggi (Tabel 3).

Tabel 2. Data tingkatan sikap belajar terhadap IPA siswa MTs. Al Ma'arif Praya Timur

\begin{tabular}{llll}
\hline $\begin{array}{l}\text { Skor } \\
\text { sikap } \\
\text { belajar }\end{array}$ & $\begin{array}{l}\text { Kriteria } \\
\text { tingkatan } \\
\text { sikap } \\
\text { belajar IPA }\end{array}$ & $\begin{array}{l}\text { Jumlah } \\
\text { siswa } \\
\text { (orang) }\end{array}$ & $\begin{array}{l}\text { Persentase } \\
(\%)\end{array}$ \\
\hline $76-100$ & Sangat Suka & 5 & 25 \\
$51-75$ & Suka & 15 & 75 \\
$26-50$ & Kurang suka & 0 & 0 \\
$0-25$ & Tidak suka & 0 & 0 \\
\hline
\end{tabular}

Data hasil belajar siswa MTs. Al Ma'arif menunjukkan bahwa walaupun sekolah agama dan swasta yang serba terbatas baik pendanaan maupun 
fasilitas, siswanya mempunyai antusisme yang tinggi terhadap mata pelajaran IPA. Hal ini ditunjukkan dari hasil belajar IPA yang tergolong kedalam kriteria tinggi dan sedang. Hal ini didukung dengan hasil olah data angket sikap belajar siswa yang termasuk kedalam kriteria sikap positif. Hal ini disebabkan karena IPA merupakan mata pelajaran yang diujian nasionalkan pada semua jenjang dan jenis sekolah, tidak ketinggalan di sekolah agama dan swasta. Selain itu mata pelajaran IPA juga merupakan mata pelajaran yang sangat dibutuhkan dalam kehidupan dunia nyata dalam menghadapi kemajuan ilmu dan teknologi ke depan.Hasil penelitian kaitan sikap belajar dengan hasil belajar IPA ini sejalan dengan penelitian terdahulu yang yang menyatakan sikap positif siswa terhdap suatu pembelajaran akan memunculkan hasil belajar yang baik. Semakin positif sikap belajar seseorang maka semakin tinggi hasil belajar yang dicapai [38][39] [40].

Tabel 3. Data tingkatan Hasil Belajar IPA siswa MTs. Al Ma'arif Praya Timur

\begin{tabular}{llll}
\hline $\begin{array}{l}\text { Skor } \\
\text { Hasil } \\
\text { belajar }\end{array}$ & $\begin{array}{l}\text { Kriteria } \\
\text { hasil belajar }\end{array}$ & $\begin{array}{l}\text { Jumlah } \\
\text { siswa } \\
\text { (orang) }\end{array}$ & $\begin{array}{l}\text { Persentase } \\
(\%)\end{array}$ \\
\hline $91-100$ & Sangat Tinggi & 0 & 0 \\
$80-90$ & Tinggi & 6 & 30 \\
$65-79$ & Sedang & 14 & 70 \\
$64-55$ & Rendah & 0 & 0 \\
$54-0$ & $\begin{array}{l}\text { Sangat } \\
\text { Rendah }\end{array}$ & 0 & 0 \\
\hline
\end{tabular}

\section{KESIMPULAN}

Kesimpulan dari penelitian ini adalah ada kaitan yang signifikan antara sikap belajar dengan hasil belajar IPA siswa kelas II M.Ts. Al Ma'arif Praya Timur artinya semakin tinggi sikap belajar terhadap IPA semakin tinggi pula hasil belajar IPA yang diraihnya. Disarankan agar siswa mempunyai sikap yang positif terhadap pelajaran IPA agar memperoleh hasil belajar IPA yang tinggi.

Berdasarkan hasil penelitian diharapkan adanya penelitian terkait perbedaan sikap siswa perempuan dan laki-laki terhadap pelajaran IPA. Hal lain yang perlu diteliti yakni sikap siswa terhadap pelajaran IPA dari sudut pandang yang berbeda seperti sikap guru, motivasi dan lain-lain. Penelitian lanjutan terkait metode dan teknik mengajar untuk meningkatkan minat belajar dalam rangka menguatkan sikap positif siswa terhadap pembelajaran IPA juga perlu dilakukan.

\section{DAFTAR PUSTAKA}

[1] Dongoran, F. R. (2014). Paradigma Membangun Generasi Emas 2045 dalam Perspektif Filsafat
Pendidikan. Jurnal Tabularasa PPS Unimed, 11(1). 61-76.

[2] OECD. (2014). Student Learning: Attitudes Engagement and Strategies.

[3] Qi, D. \& Wu, Y. (2020). Family's social economic status and child educational outcomes in China: The mediating effects of parenting practices and children's learning attitudes. Childrens and Youth Service Review. 118(1) 1-9.

[4] Astalini, A., \& Kurniawan, D. A. (2019). Pengembangan instrumen sikap siswa sekolah menengah pertama terhadap mata pelajaran IPA. Jurnal Pendidikan Sains (Jps), 7(1), 1-7.

[5] Şen, H. Ş. (2013). The attitudes of university students towards learning. 2nd World Conference on Educational Technology Researches - WCETR2012, 83, 947-953.

[6] Isnaini, M., Ananda, J., \& Kapitan, A. (2017). Pengaruh Bentuk Tes Formatif dan Sikap Belajar terhadap Hasil Belajar Membaca Bahasa Arab. Arabi: Journal of Arabic Studies. 2(1), 47-53.

[7] Shah, Z. A., Mahmood, N., \& Harrison, C. (2019). Attitude towards science learning: An exploration of Pakistani students Attitude towards Science Learning: An Exploration of Pakistani Students. Journal of Turkish Science Education, 10 (02), 35-47.

[8] Darmaji, D., Kurniawan, D.A., Suryani, A. \& Lestari, A. (2018). An identification of physics pre-service teachers' science process skills through science process skills-based practicum guidebook. Jurnal Ilmiah Pendidikan Fisika AlBiruni, 7(2), 239-245.

[9] Ahmadi, H.A. (1991) Belajar dengan Efektif, Bhineka Ofset, Jakarta.

[10] Hasan, A. M. (2016). Effects of ChallengeBased Learning and Activity Based Learning Approaches on Techinal College Students Achievement, Interest and Retention in Woodwork Technology. Nigeria: Tesis tidak diterbitkan.

[11] Abubakar, M.T. (2014). Assessment of Students Performance in Automobile Technology Practical in Technical Colleges of Sokoto State. Minna: Skripsi tidak diterbitkan.

[12] Anderson, L. W. \& Krathwohl, D. R. (2015). Kerangka Landasan untuk Pembelajaran, Pengajaran \& Asesmen. Revisi taksonomi Bloom. (Prihantoro, Trans). Yogyakarta: Pustaka Pelajar.

[13] Raved, L., Ben, O., Assaraf, Z., Raved, L., Ben, O., \& Assaraf, Z. (2011). Attitudes towards Science Learning among 10th - Grade Students: A qualitative look. International Journal of Science Education. 33 (9).

[14] Maulana, I. (2016). Pengaruh Strategi Pembelajaran PBL dan TPS terhadap Keterampilan Metakognitif, Keterampilan 
Berpikir Kritis, Sikap Sosial, Hasil Belajar Biologi dan Retensi pada Siswa dari Etnis yang Berbeda di Kota Metro. Disertasi tidak diterbitkan.

[15] Saifuddin Azwar, (1988), Sikap Manusia teori dan Pengukurannya, Liberty, Yogyakarta.

[16] Osborne, J., Simon, S., \& Collins, S. (2003). Attitudes towards science: A review of the literature and its implications. International. Journal of Science Education, 25, 1049-1079.

[17] Oemar, Hamalik. (2001). Pendekatan Baru Strategi Belajar mengajar berdasarkan CBSA. Sinar Baru Algensindo. Bandung.

[18]Dadang Sulaiman. (1984). Sumbangan Kecerdasan, Motif Berhasil, Sikap Belajar dan Kebiasaan Belajar terhadap Hasil belajar Siswa SMA se Jawa barat, Warta Penelitian, Lembaga penelitian IKIP Bandung, Bandung

[19] Dimyati. (1999). Belajar dan Pembelajaran, Rineka Cipta, Jakarta

[20]Rizqiani, F. M. (2019). Keefektifan Model Pembelajaran Numbered Head Together Terhadap Sikap Belajar dan Hasil Belajar Siswa pada Tema 2 , Sub Tema 1 . Sumber Energi. Jurnal Ilmiah Sekolah Dasar, 2(4), 420-425.

[21] Sidik, P., \& Madawistama, S. T. (2019). Analisis Sikap Belajar Peserta Didik dalam Pembelajaran Matematika melalui Model Pembelajaran Kontruktivisme. Prosiding Seminar Nasional \& Call For Papers Program Studi Magister Pendidikan Matematika Universitas Siliwangi, 475-481.

[22] Sinson, M., \& Wedyawati, N. (2017). Analisis Sikap Belajar Siswa Kelas Tinggi pada Mata Pelajaran Ilmu Pengetahuan Alam (IPA). VOX EDUKASI, 8, 22-29.

[23] Arikunto S. (2003) Prosedur Penelitian, PT Rineka Cipta, Jakarta.

[24] Arif, L., \& Samidjo. (2018). Hubungan antara Sikap Belajar dan Motivasi Belajar Kejuruan dengan Hasil Belajar Gambar Teknik. Jurnal Taman Vokasi, 6, 92-97.

[25] Yusri, M. A. K. (2015). Hubungan Sikap Belajar dengan Hasil Belajar Mahasiswa Jurusan KTP FIP UNP dalam Mata Kuliah Komputer Grafis. Jurnal Ilmiah Ilmu Pendidikan, XV (1), 54-57.

[26] Papanastasiou, E.C., and Zembylas, M. (2004). The Effect of Attitudes on Science Achievement: A Study Conducted among High School Pupils in Cyprus. International Review of Education, 48(6), 469-484.

[27] Narmadha, U. \& Chamundeswari, S. (2013). Attitude towards Learning of Science and Academic Achievement in Science among Students at the Secondary Level. Journal of Sociological Research, 4(2), 114-124.

[28] Suyobroto. (1997). Proses Belajar Mengajar di Sekolah, Rineka Cipta, Jakarta.
[29] Wina Senjaya. (2008). Strategi Pembelajaran; Berorientasi Standar Proses Pendidikan. Kencana Prenada Media Group. Jakarta.

[30] Sartina, \& Indarto, S. (2019). Pengaruh Motivasi Belajar, Lingkungan Sosial, dan Sikap Belajar Terhadap Hasil Belajar Ekonomi di SMA / MA. Jurnal Ilmu-Ilmu Sosial, 16(1), 87-100.

[31] Rennie, L.J., and Punch, k.E. (1991). The Relationship between affect and Achievement in Science. Journal of Research in Science Teaching, 28, 93-209.

[32] Thaeb, M. R. (2016). Menumbuhkan Sikap Siswa dalam Hasil Belajar. Lantanida Jurnal, 4(1), 50-59.

[33] Nurhasanah, S. \& Sobandi, A. (2016). Minat Belajar sebagai Determinant Hasil Belajar. Jurnal Pendidikan Manajemen Perkantoran, 1(1), 128-135.

[34] Tjahjana, D. \& Arief, Z. A. (2016). Pengaruh Model Pembelajaran Problem Based Learning dan Sikap Peserta Didik Terhadap Hasil Belajar PPKn Kelas X di SMK Negeri 1 Bojonggede Kabupaten Bogor. Jurnal Teknologi Pendidikan, 5(1), 98-127.

[35] Achdiyat, M., \& Warhamni, S. (2018). Sikap Cara Belajar dan Prestasi Belajar. Faktor Jurnal Ilmialh Kependidikan, 5(1), 49-58.

[36]Ali, M. (2000) Guru dalam Proses Belajar Mengajar, PT. Sinar Baru Algensindo, Bandung.

[37] Jach, J. Y. (2004). Attitude toward Learning Science of Students in Introductory Geology Courses. Teaching Earth Education, 29(2), 2831.

[38] Jemudin, F. D. E., Makur, A. P., \& Ali, F. A. (2019). Hubungan Sikap Belajar dan Motivasi Belajar terhadap Prestasi Belajar Matematika Siswa SMPN Langke Rembong. Journal of Honai Math, 2(1), 1-11.

[39] Saefullah, A., Siahaan, P., \& Sari, I. M. (2013). Hubungan antara Sikap Kemandirian Belajar dan Prestasi Belajar Siswa Kelas X pad Pembelajaran Fisika Berbasis Portofolio. Jurnal Wahana Pendidikan Fisika, 1, 26-36.

[40] Trisnowali, A. (2017). Pengaruh Motivasi Berprestasi, Minat Belajar Matematika, dan Sikap Belajar Matematika terhadap Hasil Belajar Matematika pada Siswa SMAN 2 Watampone. Jurnal Matematika Dan Pembelajaran, 5(2), 259-278. 